\title{
University students' representations of Europe and self-identification as Europeans: a synthesis of qualitative evidence for future policy formulation
}

\author{
Esther Cores-Bilbao ${ }^{1 *}$ (D) María del Carmen Méndez-García² (D) and M. Carmen Fonseca-Mora ${ }^{3}$ (D)
}

\begin{abstract}
The current European context is characterised by the emergence of socio-political tensions that threaten to derail the cohesion objectives traditionally promoted by the authorities of the European Union. With EU citizenship in the shadow of Brexit, the fear of dismemberment of the current Europe of the 28 looms over a renewed debate on concepts like European identity, European citizenship or EU legitimacy and the involvement of its constituents in European affairs, as well as the role of education for promoting democratic awareness among young Europeans. This work aims to collect, appraise and synthesise qualitative evidence obtained in primary research exploring the perceptions of European university students about their civic and cultural identity. This systematic analysis sets out to identify predictors of positive self-identification with the EU and its institutions, focusing on the impact that different educational interventions have had on the attitudes and perceptions expressed by university students, and the importance of foreign language learning in the results obtained. The authors report their assessment of quality of the findings in a Cochrane-style qualitative evidence synthesis (QES), based on the GRADE-CERQual (Confidence in Evidence from Reviews of Qualitative research) method. The 12 informed findings described in this study support decision-making in future education policy formulation.
\end{abstract}

Keywords: European identity, Higher education students, Erasmus, Nested identities, Qualitative evidence synthesis (QES), Confidence in Evidence from Reviews of Qualitative research (GRADE-CERQual), Education policy formulation

\section{Introduction}

After decades of careful political, strategic and educational planning in pursuit of a European identity that citizens of all the member states could stand behind, the Union faces its biggest challenge to date: the rise of nationalist ideologies that propose to de-link from the supranational community agenda. The ensuing media and public attention shift to current and latent political participation of Europeans, as well as to the role of foreign language education for promoting the European dimension in citizenship education among the younger generations, sowed the seeds for the present research.

\footnotetext{
* Correspondence: esther.cores.edu@juntadeandalucia.es

'Departamento de Pedagogía, Facultad de Educación, Psicología y Ciencias del Deporte, Universidad de Huelva, Avda. de las Fuerzas Armadas, s/n, 21071 Huelva, Spain

Full list of author information is available at the end of the article
}

Most studies addressing the formation of a European identity have solely focused on adult participants and the relatively scarce number of studies that have tackled younger subjects have obtained contradictory results $[13,37]$. However, it is in fact young people who are more likely than other age groups to see themselves as European, as they tend to manifest cosmopolitan ideals, identities and conducts (Woodward et al., 2008 in [14]).

Research dealing with European identity in higher education contexts has mainly focused on the quantitative evaluation of international study sojourns and their impact on the undergraduate students' competence development, personal growth and self-identification [18-20, $23,31,39]$. This body of research generally affirms that, although in varying degrees, cross-cultural experience builds up the participants' repertoire to re-examine their cultural and contextual assumptions or worldviews. 
Unsurprisingly, in the recent years, one of the EU's flagship education programmes has been Erasmus+ 2014-2020, an initiative aimed at promoting a sense of European identity and citizenship among higher education students via intra-European mobility experiences. In addition to pursuing the European Union's need to compete in the global sphere, forging 'global citizenry', the rationale behind this programme is the belief that by bringing young Europeans together, a sense of European identity can be fostered [37, 38].

For its foreseen continuation spanning the 2021-2027 period, which has been allocated sizable budgetary increases, the legislative proposal drafted by the European Parliament reasserts that learning mobility contributes to strengthening European identity, principles and values and to bolstering a more democratic Union.

In light of the above, an exhaustive summary of current empirical evidence relevant to university students' perceived European civic and cultural identity, with particular focus on the outcomes of educational programmes and on other factors that may facilitate or hinder its advancement, become highly relevant.

\section{The construction of the European collective identity}

European identity has been defined by political theorists as 'a psycho-sociological or socio-political process of attachment to the European space or to the political community designed by integration' ([6], translated by [28]). From an anthropological perspective, European identity is a collective identity which is accepted by individuals who share fundamental ethnic and civic similarities, being bound by a common historical heritage and feeling reciprocal solidarity [2].

This triple civic, spatial and ethnocultural domain of identification with Europe has been addressed by EC/EU policies in efforts to foster a European identity among the citizenship. For the most part, however, the initiatives undertaken have been beset of ambiguities [27], and European officials have recurrently acknowledged that public opinion does not understand the EU, emphasising the need to improve, enable, engage and empower citizens to exercise their right to participate in the democratic life of the Union [36].

The main purpose of this review is to elucidate European identity contents (what Europe is in university students' minds) to verify the compatibility of subnational, national, and super-national identities within this population, to ascertain local enabling factors of identification with Europe and to infer the causal dynamics between European identity-taking and foreign country sojourns and language learning experiences (in the case of mobile students) or domestic cognitive transnationalization (in the case of nonmobile students). The main thread here is that formative years at university, pivotal to students' individual life course and life projects, are also decisive in supranational, collective identity-formation. It is at this stage in life that innovative policy development in the fields of education, training and youth, particularly those pursuing inclusive, democratic, cohesive and resilient societies can have substantial lifelong impacts.

The personal traits and contextual characteristics which predispose individuals to identify themselves with certain supranational entities is a topic still vigorously debated by psychology scholars. Even within the realm of pedagogy and education, studies pursuing this line of research are compartmentalised and sometimes cast conflicting findings. Therefore, conducting a qualitative evidence synthesis (QES) is a means of making sense of the existing information and dissipating areas of uncertainty regarding the efficacy of preceding educational initiatives. An account of the different policies launched to achieve political legitimacy and social cohesion among EU nationals over the years is beyond the scope of this review (for further insight, see $[2,30])$, as what we pursue to establish is their reception by young Europeans.

This approach is original, as authors do not adhere to a descriptive narrative review on the subject, but rather apply the GRADE-CERQual (Confidence in Evidence from Reviews of Qualitative research) analytical method to evaluate the quality of the presented findings $[15,16]$, whose objective is to support the use of findings from qualitative evidence syntheses in decision-making, namely policy formulation.

A QES can be an aggregative or interpretive process which requires a transparent research protocol and the authors' finesse to accurately represent the findings extracted from the studies included in the review [22]. Hence, academics are progressively regarding qualitative evidence syntheses as complete studies, comparable to any meta-analysis on the effects of interventions.

\section{Objectives}

The specific objectives of this review are to identify, appraise and synthesise qualitative studies exploring the following:

- Perceptions of European identity and ethos among European university students.

- Predictors of endorsement of the EU by European university students.

- Impact of foreign country experiences on the students' identification with Europe.

- Contribution of foreign language learning to the development of social cohesion, active citizenship and intercultural awareness. 


\section{Method}

\section{Selection of the corpus}

The criteria for considering studies for this review referred to the types of studies, the types of participants and the types of phenomena of interest analysed. Due to the scope of the topic dealt with, our review focuses on findings of qualitative research, which "provide much more detailed in-depth information about meanings of interventions and of behaviours" ([25], 77). While surveys and other quantitative tools may include questions on identity, qualitative methods are better suited for assessing the placement or fluidity of perceived borders between these identities and the meaning attributed to certain identities. This review encompasses the results obtained from qualitative primary research studies, as well as qualitative findings extracted from mixedmethod inquiries.

Eligible studies were identified in a 3-step process, conducted by two reviewers. First, an electronic database search was performed, supplemented by hand searching. The electronic search was conducted in Proquest, Scopus and WOs from database inception to 30 May 2018. No date or geographical restrictions were imposed, although the challenges associated with translating papers reporting qualitative research limited our selection to articles published in languages spoken by at least two members of the review team (i.e. French, English and Spanish).

The search strategy was guided by two main elements, European university students and their identification with Europe, following this syntax:

- TI,AB,IF(“European identity" OR "European identification") AND TI,AB,IF("supranational identity" OR "global identity" OR "supranational identification" OR "global identification") AND TI,AB,IF("university students" OR "college students" OR "higher education" OR "tertiary education" OR "young adults").

- TI,AB,IF(“European identity" OR "European identification") AND TI,AB,IF("university students" OR "college students" OR "higher education" OR "tertiary education" OR "young adults").

The electronic database search yielded 77 studies, and the hand search produced 6 additional papers, all of which were published between 1998 and 2016. Records identified from the different sources were collected and sorted into one database, removing 5 duplicates. The titles and abstracts of the identified records were independently assessed to gauge their potential eligibility. During this first screening, 16 studies that were clearly irrelevant to the topic of this review, based on the population age group described in article titles and abstracts, were discarded.
Second, the full text of all the papers that were likely to be relevant was retrieved and independently assessed based on the review's inclusion criteria. During this second screening, 19 articles lacking an empirical analysis of data or focusing on a population other than university students were excluded.

Third, the remaining 43 empirical studies which complied with the inclusion criteria in terms of defined study population were screened to set apart quantitative work. Only qualitative or mixed-method studies were retained at this stage. Disagreements were resolved through discussion or, if required, by seeking a third review author's view. This third screening yielded the final cohort of 8 qualitative, and 11 mixed-method studies have been included in this synthesis (Fig. 1).

\section{Study respondents}

In all of the studies but one, authors sought the perspectives of undergraduate university students. The exception was an article which focused on the perceptions of researchers and postgraduate students. A significant percentage of respondents were enrolled in social sciences, teaching and foreign language programmes.

\section{Setting}

The studies are characterised by a wide geographical dispersion, with respondents located in 32 different universities across Europe and a higher presence in the UK (9) and Germany (6) (Fig. 2).

\section{Quality of the included qualitative studies}

All the included studies were published as papers in indexed research journals, which constitutes a sound quality threshold. Descriptions, even if very brief, about the participants, sampling, methods and analysis are always provided. Most of the studies used interview or focus group discussions with very few instances of other methods of data collection.

To verify the quality of included studies, the Critical Appraisal Skills Programme (CASP) checklist for qualitative studies [3] was used, which contains 10 questions to systematically ascertain the validity, rigour and contribution that the studies make to pre-existing knowledge or understanding. However, this assessment of quality was merely conducted to validate the relative contribution of each study to the development of explanations to our research questions, not to exclude any of the pooled studies.

\section{Assessment of confidence in the review findings}

Our review findings were assessed by applying the four key components recommended by the GRADEConfidence in the Evidence from Reviews of Qualitative research (GRADE-CERQual) $[15,16]$ : 


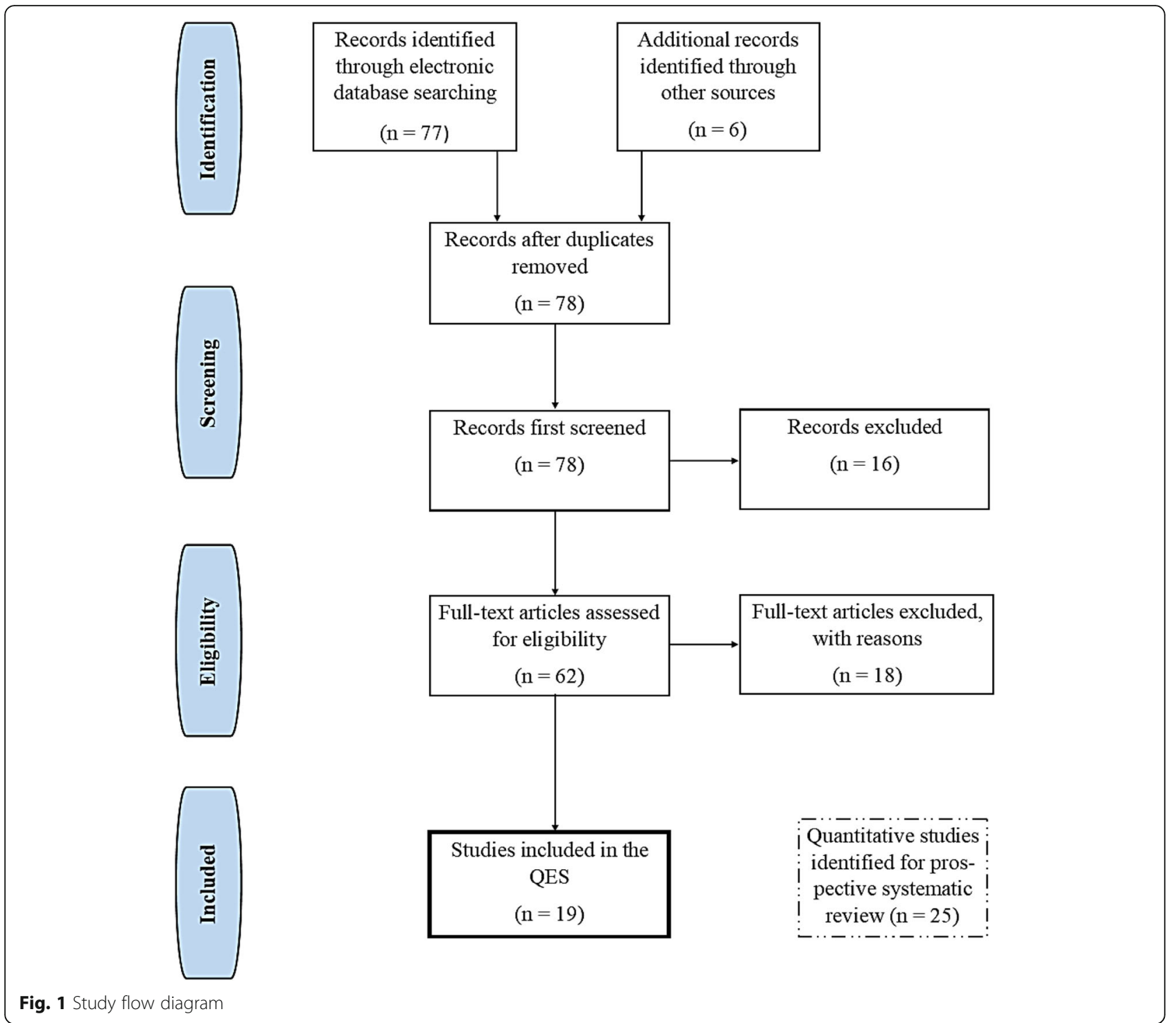

- Analysis of the possible methodological limitations of included studies.

- Evaluation of coherence of the review finding by analysing the primary studies on which the study was grounded and if a convincing explanation for patterns was found in the data.

- Rating of adequacy and overall determination of the degree of richness and quantity of data supported by the findings of the study.

- Judgement of the relevance of the included studies to the review question and its application to the context (population, phenomenon of interest, setting) specified in the review question.

After assessing each of the four components, qualified reviewers judged the overall confidence in each review finding to be high, moderate, low or very low $[15,16]$. In order to allocate a confidence rating, reviewers proceeded on the basis that all the findings were "high confidence' and marked them down only when concerns regarding any of the CERQual components [18] that would weaken this assumption were identified.

\section{Data synthesis}

A thematic analysis using a constant comparison strategy was performed, applying a 5-step process to undertake the data synthesis. Firstly, the article judged to most closely answer the review objectives was chosen. Secondly, this article was coded using a thematic analysis approach. Thirdly, a data extraction sheet based on the codes that emerged from the previous step was created. Then, data from all of the sampled articles was extracted, altering the data extraction sheet if new themes emerged from the subsequent articles. Finally, the data 


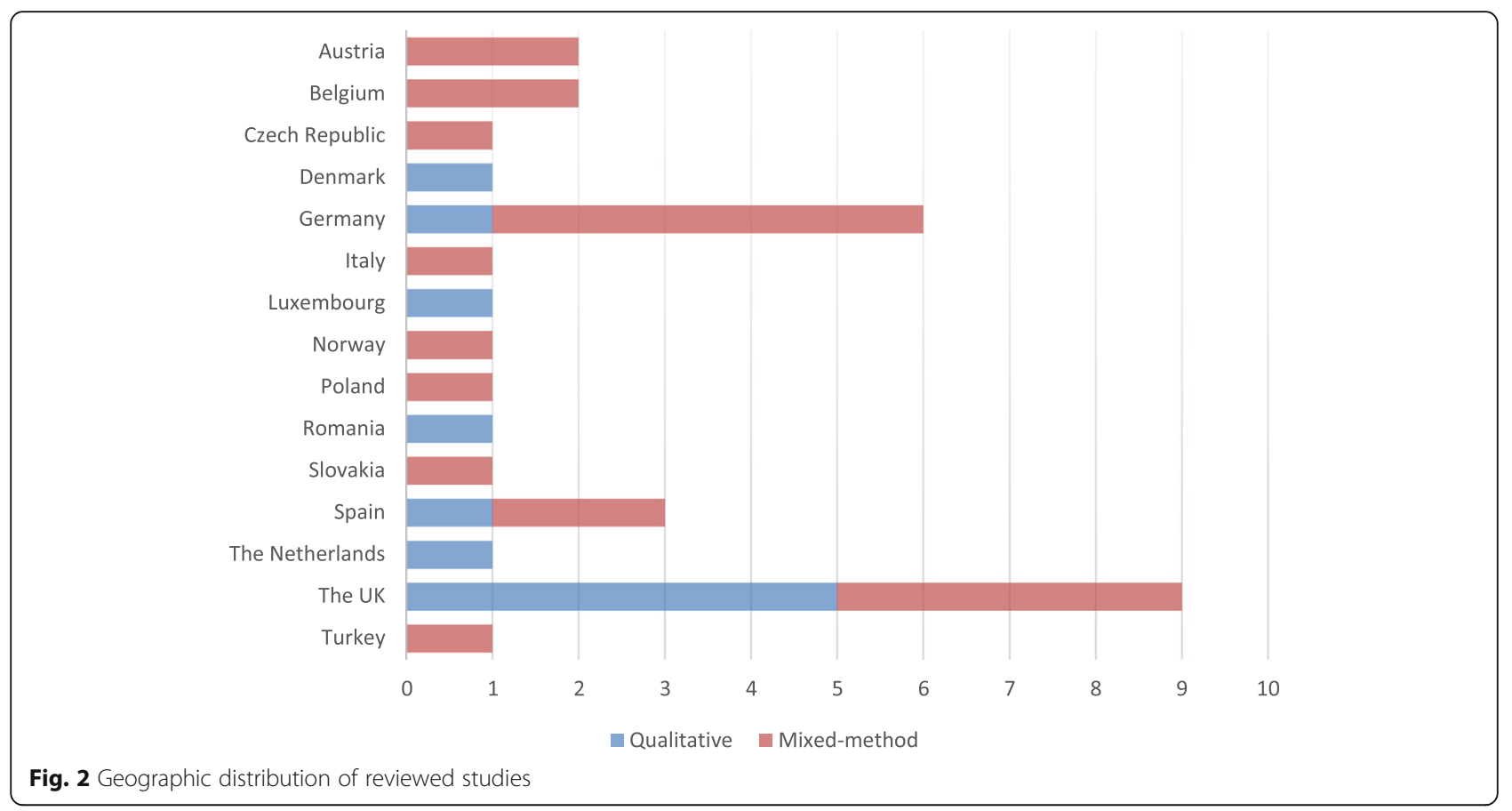

were synthesised and the included studies were re-read to confirm that all data relevant to the findings had been extracted.

\section{Categories and findings identified in the data}

From the constant comparison thematic synthesis, 4 overarching categories were identified: European ethos, self-identification, predictors of endorsement and opposition, and foreign country experiences. Table 1 'Summary of qualitative findings' (SoQF) contains an overview of the most salient information, to facilitate the understanding and use of our 12 review findings. The SoQF table is considered the entry point to the full review $[15,16]$, and as such, it provides an outline of the findings sorted by categories, the contributing papers per finding, our assessment of confidence in the evidence, as well as an explanation of the assessment based on the GRADE-CERQual approach.

When interpreting the CERQual assessment results, it is noteworthy that the relative weight of the issues detected may vary depending on the size of the supporting evidence for each of the review findings. For instance, a methodological limitation in one contributing study may be cause for minor concern when the finding relies on six additional contributing papers. However, the same methodological limitation may be cause for moderate concern if the total amount of contributing studies that endorse a given finding is lower.

\section{Synthesis findings}

Table 2 presents a summary of the contextual information pertaining to the contributing studies of this qualitative evidence synthesis.

Individual CERQual evidence profile tables are provided below, supporting the assessment of confidence in every finding. Each profile table contains at-aglance information, followed by detailed evidencebased results.

Finding 1 reports the values which are attributed to European societies by university students (Table 3 ).

As shown in Table 3 studies support finding 1: Multilingualism, cultural diversity and the promotion of human rights are consistently identified as 'European values'. These 9 studies examine values attributed to Europeanness, reporting somewhat different but complementary understandings of the construct. Predominantly, representations of Europe are associated with democratic principles, civic cooperation, peaceful co-existence, political stability, human rights and the protection of individual freedoms $[5,11,18,24,33]$. Shared traditions, ethnic diversity, similar cultural referents and civilizational meanings, alongside a common historical background among Western nations are identified as the source of affinities among European nationals [5, 18, 29, 33, 35]. From an economic perspective, wealth, liberalism and the Euro currency are emphasised [29] while the salience of spatial proximity for establishing affinities between nations is only mentioned in one study [32].

Finding 2 confirms that perceptions of what it means to be European are context-dependent (Table 4). 


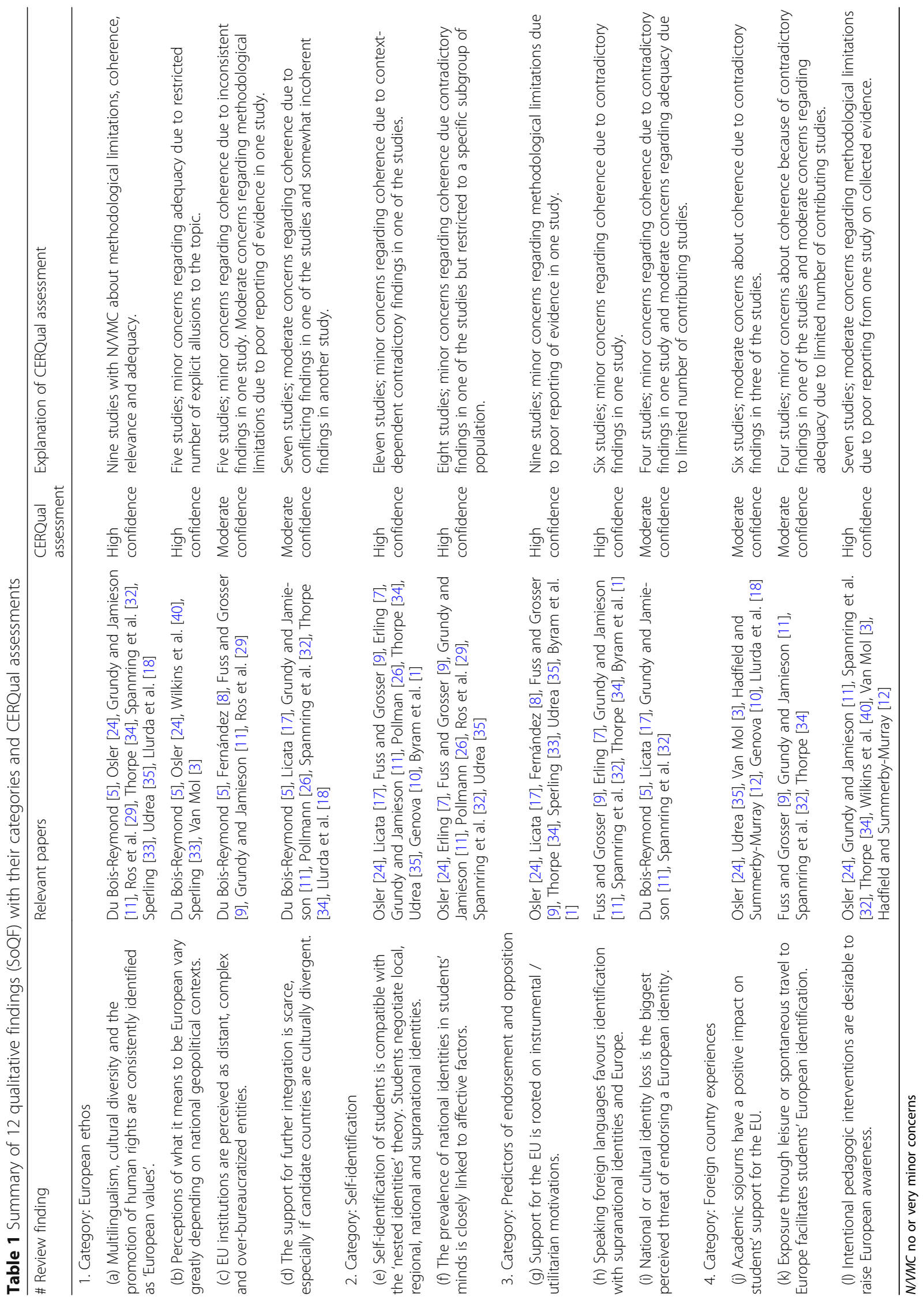


Table 2 Contextual information of the studies included in QES

\begin{tabular}{|c|c|}
\hline Contributing studies & Setting and population \\
\hline Byram et al. (2017) & $\begin{array}{l}\text { Luxembourg; student-researchers in Psychology, Law, Linguistics, History, Sociology, Sociolinguistics, and Education } \\
\text { Sciences. }\end{array}$ \\
\hline Du Bois-Reymond (1998) & Germany, The Netherlands and the UK; students enrolled in education and/or social work degrees. \\
\hline Erling (2007) & $\begin{array}{l}\text { Germany; German students and international students from Bulgaria, France, Hungary, Korea and Poland, studying } \\
\text { English at a German university. The latter comprise both foreign students and students on official European or } \\
\text { international exchanges. }\end{array}$ \\
\hline Fernández (2005) & $\begin{array}{l}\text { The UK; European undergraduate students on exchange programmes such as Erasmus and postgraduates on } \\
\text { master's or PhD programmes. }\end{array}$ \\
\hline Fuss and Grosser (2006) & $\begin{array}{l}\text { Selected European regions: Spain (Madrid and Bilbao), Austria (Vienna and Bregenz), UK (Manchester and Edinburgh), } \\
\text { Germany (Chemnitz and Bielefeld), Czech Republic (Prague) and Slovakia (Bratislava); representative samples of 18-24 } \\
\text { years residents versus samples of resident peers engaged in Europe-oriented work or study. }\end{array}$ \\
\hline Genova (2016) & $\begin{array}{l}\text { The UK; Undergraduate and postgraduate Bulgarian students enrolled in universities in London, Wales, Scotland, } \\
\text { Southwest England the Midlands and Northern England. }\end{array}$ \\
\hline Grundy 2007 & $\begin{array}{l}\text { Scotland and the UK; representative sample of 18-24 years residents versus a sample of resident peers engaged in } \\
\text { Europe-oriented work or study. }\end{array}$ \\
\hline $\begin{array}{l}\text { Hadfield and Summerby- } \\
\text { Murray (2015) }\end{array}$ & Institute for European Studies (Brussels, Belgium); graduate students (a dozen different EU citizenships) \\
\hline Licata (2003) & Belgium; French-speaking Belgian Psychology students. \\
\hline Osler (1998) & The UK and Denmark; student teachers from Austria, Belgium, Denmark, France, Finland, Spain and Sweden. \\
\hline Pollmann (2007) & Germany; prospective history and social studies teachers from two German teacher education colleges. \\
\hline Ros et al. (2008) & $\begin{array}{l}\text { Check and Slovak Republics, Germany and Spain; European youngsters; students of European and International Law } \\
\text { or Philology; workers at multinational companies. }\end{array}$ \\
\hline Spannring et al. (2008) & $\begin{array}{l}\text { Selected European regions: Spain (Madrid and Bilbao), Austria (Vienna and Bregenz), UK (Manchester and Edinburgh), } \\
\text { Germany (Chemnitz and Bielefeld), Czech Republic (Prague) and Slovakia (Bratislava); representative samples of 18-24 } \\
\text { years residents versus samples of resident peers engaged in Europe-oriented work or study. }\end{array}$ \\
\hline Sperling (2013) & $\begin{array}{l}\text { Spain; Young adults of Latin American-immigrant descent (Dominican and Colombian), either arrived in the country } \\
\text { of residence by or before age } 12 \text { or born in the country of residence. }\end{array}$ \\
\hline Thorpe (2008) & $\begin{array}{l}\text { Scotland; Scottish representative sample of } 18-24 \text { years residents versus a sample of resident peers engaged in } \\
\text { Europe-oriented work or study. }\end{array}$ \\
\hline Udrea (2013) & $\begin{array}{l}\text { Romania; Romanian students who have recently completed or are about to complete their university studies in the } \\
\text { UK }\end{array}$ \\
\hline Van Mol (2013) & $\begin{array}{l}\text { Nine universities in Austria, Belgium, Italy, Norway, and Poland; students of Social and Political Sciences, Language } \\
\text { Studies, Economics and Business Studies, and Engineering. }\end{array}$ \\
\hline Wilkins et al. (2010) & Turkey and the UK; student teachers enrolled in 3 Turkish universities and Leicester University in the UK. \\
\hline
\end{tabular}

Most studies reviewed disaggregate data by nationality of the informants, showing different perceptions of what Europeanness represents to each national group [24, 40]. For instance, inhabitants of peripheral and central nations, or continental Europe and the UK, differ in their representations of Europe [5]. Certain identification patterns are common to those who are geographically or otherwise akin, like Scandinavian countries [3,5]. However, diverse conceptualisations are also present within groups of the same nationality, which can be explained by the existence of different past political regimes. Differences are also explained by the time of the country's annexation to the EU [3]. British students' data are reported separately, due to their country's 'isolation' from the European political unification [5].

Finding 3 points to the fact that EU institutions are considered distant, complex and over-bureaucratized entities (Table 5).
Initiatives to have youngsters identify with Europe have been unsuccessful due to their frustration about European politics and politicians [5, 32], as well as the perceived complexity and abstractness of the European Union and its institutions [8, 9]. The lack of a clear understanding of European affairs-a significant portion of respondents had trouble distinguishing 'Europeans' from 'citizens of the EU' when identifying themselves-or of the impact that civic participation would entail, has led to the youngsters' disengagement from supranational decision-making and its media coverage $[8,29]$. The perception that European politics has no significant transcendence in the everyday personal lives of higher education students is also identified as causal to this lack of interest $[9,29]$. Nevertheless, one study [11] pointed out different claims made by a small percentage of its informants about their endorsement of European 
Table 3 CERQual evidence profile. F1: Multilingualism, cultural diversity and the promotion of human rights are consistently identified as 'European values'. Category: European Ethos

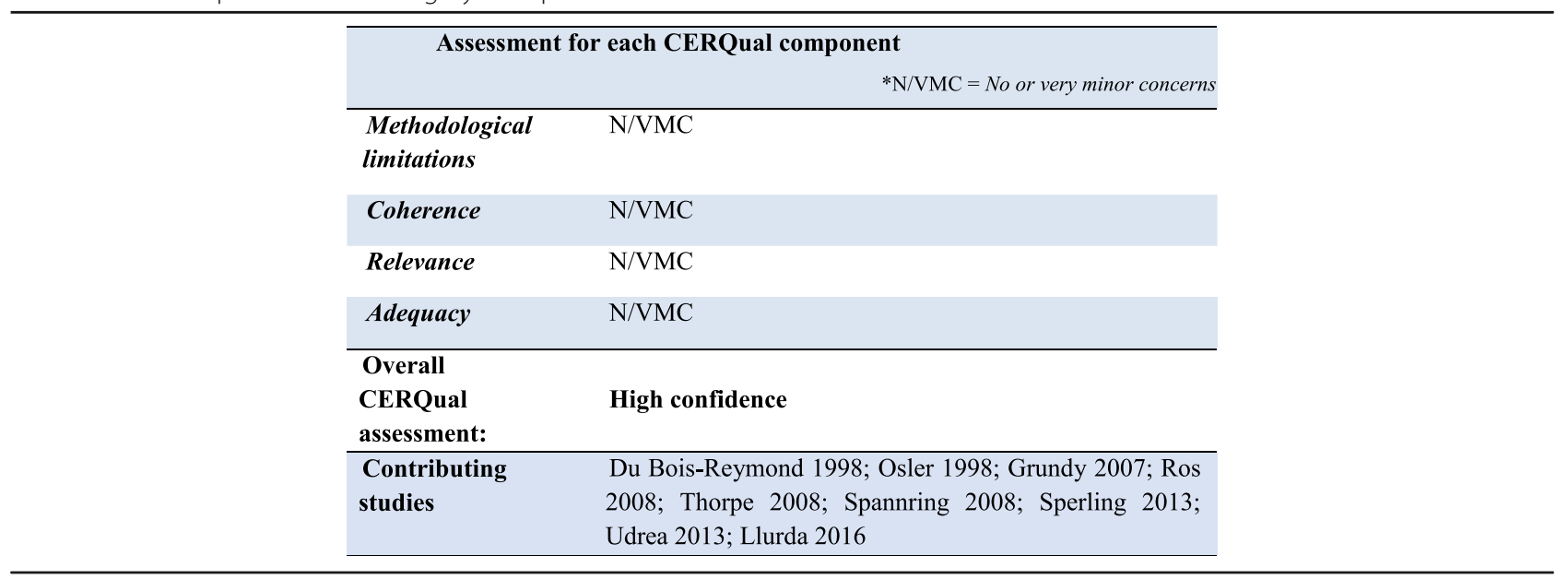

NNMC no or very minor concerns

institutions. In this context, one subject considered European institutions as the nurturers of informal civil action and values.

Finding 4 reveals that university students are disinclined to support further integration and Eastward expansion of the EU (Table 6).

One of the studies reported overt disagreement with Turkey's prospective inclusion in the EU. Issues regarding inclusion of new member states were tackled without the interviewer mentioning a specific nationality, yet all interviewees chose the example of Turkey and Turkish immigrants to illustrate their notions of the EU, based on shared concerns about the human rights situation in that country, its remote geographical location and presumably different religious background [26]. Another study pointed out that the mounting anti-immigrant sentiment in many European nations may lead to exclusionary views of Europeanness [33]. Similarly, other studies cite in-group identification of 'distinctive European traits' to justify dissimilarities to other countries beyond European borders $[18,32]$ and to prevent certain culturally diverging candidate countries like Turkey from joining the EU [34]. Nonetheless, one study emphasised the respondents' wish for Europe not to become homogeneous and their view of cultural standardisation as a threat to cultural identity [11]. Along the same line, another study argued that in order to gather support, European integration should be presented as a process that will maintain national distinctiveness and sovereignty [17].

Finding 5 groups those studies endorsing the compatibility of multiple identity layers within the students' selfidentification (Table 7).

In general, students acknowledge having multiple levels of identity-local, regional, national, and supranational-which emerge depending on the situation and

Table 4 CERQual evidence profile. F2: Perceptions of what it means to be European are contingent upon the national geopolitical context. Category: European Ethos

\begin{tabular}{ll}
\hline \multicolumn{1}{c}{ Assessment for each CERQual component } \\
*N/VMC = No or very minor concerns
\end{tabular}


Table 5 CERQual evidence profile. F3: EU institutions are seen as distant, complex and over-bureaucratized entities. Category: European Ethos

\begin{tabular}{ll}
\hline \multicolumn{1}{c}{ Assessment for each CERQual component } \\
*N/VMC = No or very minor concerns
\end{tabular}

N/VMC no or very minor concerns

context $([1,9,10,26])$. One study argued that European identification relies on pre-existing national identifications on the social representations of the relations between the EU and the subordinate geopolitical entity [17]. Authors also propose that we should think of students as having identity layers, corresponding to their local, national, European and global affiliations (Erling, 2007). These layers of identity are often hierarchised in students' minds and though national identity feelings are commonly stronger, most participants revealed their
European identity feelings were not entirely eclipsed by national identifications $([7,10,35])$. Some studies point to European identity not being the students' primary place of identification, but an additional identity marker of social distinction $([7,34])$.

Byram [1] and Udrea [35] concluded that mobile students tend to assimilate European and 'international student' identities, considering them interchangeable. Encounters with international students usually triggered a self-reflection and increased awareness of their own

Table 6 CERQual evidence profile. F4: The support for further integration is scarce. Category: European Ethos

\begin{tabular}{ll}
\hline \multicolumn{2}{c}{ Assessment for each CERQual component } \\
$\begin{array}{ll}\text { Methodological } \\
\text { limitations }\end{array}$ & N/VMC \\
Coherence & N/VMC $=$ No or very minor concerns \\
Relevance & N/VMC \\
Adequacy & N/VMC \\
\hline $\begin{array}{l}\text { Overall } \\
\text { CERQual } \\
\text { assessment: }\end{array}$ & High confidence \\
\hline $\begin{array}{l}\text { Contributing } \\
\text { studies }\end{array}$ & $\begin{array}{l}\text { Du Bois-Reymond 1998; Osler 1998; Grundy 2007; Ros } \\
\text { 2008; Thorpe 2008; Spannring 2008; Sperling 2013; } \\
\text { Udrea 2013; Llurda 2016 }\end{array}$ \\
\hline
\end{tabular}


Table 7 CERQual evidence profile. F5: Self-identification is compatible with the 'nested identities' theory. Category: Self-identification

\begin{tabular}{|c|c|}
\hline \multicolumn{2}{|c|}{ Assessment for each CERQual component } \\
\hline & ${ }^{*} \mathrm{~N} / \mathrm{VMC}=$ No or very minor concerns \\
\hline $\begin{array}{l}\text { Methodological } \\
\text { limitations }\end{array}$ & $\mathrm{N} / \mathrm{VMC}$ \\
\hline Coherence & $\begin{array}{l}\text { Minor concerns due to context-dependent } \\
\text { contradictory findings in one of the studies (Grundy) }\end{array}$ \\
\hline Relevance & $\mathrm{N} / \mathrm{VMC}$ \\
\hline Adequacy & N/VMC \\
\hline $\begin{array}{l}\text { Overall } \\
\text { CERQual } \\
\text { assessment: }\end{array}$ & High confidence \\
\hline $\begin{array}{l}\text { Contributing } \\
\text { studies: }\end{array}$ & $\begin{array}{l}\text { Osler 1998; Licata 2003; Fuss 2006; Erling 2007; } \\
\text { Pollman 2007; Thorpe 2008; Udrea 2013; Genova } \\
\text { 2016; Llurda 2016; Byram } 2017\end{array}$ \\
\hline $\begin{array}{l}\text { Conflicting } \\
\text { studies: }\end{array}$ & $\begin{array}{l}\text { Grundy } 2007 \text { (very contextually-bound limitation of } \\
\text { the general finding) }\end{array}$ \\
\hline
\end{tabular}

identity, as such situations require an explanation, description or justification of one's origin $([9,35,[26])$. In some cases, students actualized a European sense of self because of the fact that they were perceived as Europeans in a foreign environment or when in contact with non-Europeans in their own country, prompting a distinctive European identity to emerge [18,35]. Under these circumstances, mobile students sometimes added another layer to their identity negotiation process: that of migrant [10]. Some students preferred to identify themselves as 'world citizens', as this idea overcame a more departmentalised conceptualisation of 'Europeans' versus 'outsiders' [24].

Nevertheless, Grundy and Jamieson [11] observed the Scottish students' lack of identification as European. The study concluded that most participants had strong Scottish national identities and some had strong feelings about their British nationalities, but had never considered themselves as European. For the majority, being European was absent from their routine and from the festive occasions which have selfdefining properties.

Finding 6 relates the prevalence of national identities over supranational identities with affective factors (Table 8).

Youngsters favour their national identity when measured from an affective perspective or a personal value [29], and many construe their national citizenship in terms of a shared culture and a sense of belonging, rather than as a legal status [24]. Several studies reveal the perceived lack of a strong emotional response or attachment to Europe $([24,26])$. For most of the interviewees, the problem of describing their feelings about Europe stems from the lack of personal experiences in which they have perceived themselves as Europeans [9]. In fact, being European does not represent a deeply rooted mode of identification but it is seen as a matter of course due. In this sense, it entails the same type of personal values and goals as national identities. On an individual level, thus, the defining elements of their European identity are personal safety, economic growth and social recognition; on a collective level, European identification is concomitant to national security $[9,29]$.

One study concluded that some aspects of the EU elicit vehement emotional responses in the students, observable during the heated discussions that took place in the focus groups, when individuals were confronted with some facet of their Europe experience (generally acquired through travelling, direct exposure to other cultures or through public and political discourse) as well as when debating topics concerned with the future of the Union. These emotional responses were more cogently manifested by students who were politically engaged [32].

Finding 7 summarises the motivations leading to the students' individual support of the EU (Table 9).

The nine studies cited corroborate that individual support for the EU correlates with the benefits that 
Table 8 CERQual evidence profile. F6: The prevalence of national identities is closely linked to affective factors. Category: Selfidentification

\begin{tabular}{|c|c|}
\hline \multicolumn{2}{|c|}{ Assessment for each CERQual component } \\
\hline & $* \mathrm{~N} / \mathrm{VMC}=$ No or very minor concerns \\
\hline $\begin{array}{l}\text { Methodological } \\
\text { limitations }\end{array}$ & $\mathrm{N} / \mathrm{VMC}$ \\
\hline Coherence & $\begin{array}{l}\text { Minor concerns due to contradictory findings in one of } \\
\text { the studies (Spannring), for a subgroup of the } \\
\text { population (politically engaged students) }\end{array}$ \\
\hline Relevance & $\mathrm{N} / \mathrm{VMC}$ \\
\hline Adequacy & N/VMC \\
\hline $\begin{array}{l}\text { Overall CERQual } \\
\text { assessment: }\end{array}$ & High confidence \\
\hline $\begin{array}{l}\text { Contributing } \\
\text { studies: }\end{array}$ & $\begin{array}{l}\text { Osler 1998; Fuss 2006; Grundy 2007; Pollmann 2007; } \\
\text { Ros 2008; Udrea } 2013\end{array}$ \\
\hline $\begin{array}{l}\text { Conflicting } \\
\text { studies: }\end{array}$ & Spannring 2008 \\
\hline
\end{tabular}

N/VMC no or very minor concerns

membership might afford on a personal level. Similarly, social groups are most likely to identify with Europe if they have something to gain by doing so [34]. A predominant theme tackled by studies is the perceived importance of freedom of movement and the elimination of custom controls when crossing internal frontiers in respondents' minds $[1,8,24,35]$. Mobility is of such importance that it encouraged several students to re-define themselves as European citizens [24]. Other perceived benefits are academic, educational and funding opportunities [1, 33, 35], employment prospects [33, 35], the right to reside without restriction in any member country, the prerogative to take any amount of money when travelling to other EU countries and the ability to make payments seamlessly anywhere in Europe [8]. A hypothetical transfer of competencies to the EU (for instance,

Table 9 CERQual evidence profile. F7: Support for the EU is rooted on instrumental / utilitarian motivations. Category: Predictors of endorsement and opposition

\begin{tabular}{|c|c|}
\hline \multicolumn{2}{|c|}{ Assessment for each CERQual component } \\
\hline & ${ }^{*} \mathrm{~N} / \mathrm{VMC}=$ No or very minor concerns \\
\hline $\begin{array}{l}\text { Methodological } \\
\text { limitations }\end{array}$ & $\begin{array}{l}\text { Minor concerns due to poor reporting of evidence in } \\
\text { one study (Fernández) }\end{array}$ \\
\hline Coherence & N/VMC \\
\hline Relevance & N/VMC \\
\hline Adequacy & N/VMC \\
\hline $\begin{array}{l}\text { Overall CERQual } \\
\text { assessment: }\end{array}$ & High confidence \\
\hline $\begin{array}{l}\text { Contributing } \\
\text { studies: }\end{array}$ & $\begin{array}{l}\text { Osler 1998; Licata 2003; Fernández 2005; Fuss 2006; } \\
\text { Pollman 2007; Thorpe 2008; Sperling 2013; Udrea } \\
\text { 2013; Byram } 2017\end{array}$ \\
\hline
\end{tabular}


regarding a European army which would undertake shared defence efforts) was sometimes also based on utilitarian considerations [26].

Finding 8 supports that speaking foreign languages favours identification with supranational identities and Europe (Table 10).

Three studies that examined this issue ascertained that students who expressed an above-average feeling of attachment to Europe generally also regarded language skills as a key factor for establishing transnational relations and developing a cosmopolitan sense of belonging to many different places $([7,9,32])$. Similarly, one study concludes that individuals who are members of the 'cultural bourgeoisie', who hold a high degree of further education and are oriented to knowledge of foreign languages, society and cultures, are more likely to positively identify with Europe [34]. By contrast, one study [11] found that respondents who held a European identity rarely attributed their affiliation to studying European languages or to their higher education, and instead ascribed it to events that occurred much earlier in their biographies, such as friendships, shared experiences, emotions and meaningful communication with European nationals from other countries.

However, foreign language learning is generally considered as a facilitator of European identity, as people seek opportunities of exchange and communication with nationals of other countries or cultures through foreign languages [32]. The connection between multilingualism and European identity is also addressed by two studies. Thus, command of English is perceived as a marker of affinity with Europe and of holding a multilingual identity [7]. Multilingual competence, in turn, is used to distinguish between being a European researcher and an international researcher when in 'the rest of the world' [1].

Finding 9 attests university students' fear for their national cultural identity in the Pan-European cultural arena (Table 11).

Three studies reported the respondents' concerns regarding Europe becoming too homogeneous and their view of cultural standardisation, loss of national power and lack of respect for regional cultures as a threat to the desirable culturally distinct identity of each nation $([5,11$, 17]). In contrast, one study contributed evidence that exposure to other cultures may help to generate a consciousness of national or regional distinctiveness or even rejection of the other cultures to which one is exposed [32].

Finding 10 indicates that academic sojourns possibly have a positive impact on students' support for the EU (Table 12).

Some studies considered educational mobility pivotal in facilitating the students' assumption of a European sense of belonging, as some respondents argued that without the opportunity to study abroad and the experiences derived from it, their sense of Europeanness would have remained a lot less prominent $([3,35])$. Similarly, some studies suggest that education through mobility remains a highly viable means of (re)constructing identity

Table 10 CERQual evidence profile. F8: Speaking foreign languages favours identification with supranational identities and Europe. Category: Predictors of endorsement and opposition

\begin{tabular}{ll}
\hline \multicolumn{2}{c}{ Assessment for each CERQual component } \\
$\begin{array}{ll}\text { Methodological } \\
\text { limitations }\end{array}$ & N/VMC \\
\hline Coherence & $\begin{array}{l}\text { Minor concerns due to contradictory findings in one of } \\
\text { the studies }\end{array}$ \\
Relevance & N/VMC \\
$\begin{array}{ll}\text { Adequacy } \\
\text { Overall } \\
\text { CERQual } \\
\text { assessment: }\end{array}$ & N/VMC \\
\hline $\begin{array}{l}\text { Contributing } \\
\text { studies: }\end{array}$ & High confidence \\
\hline $\begin{array}{l}\text { Conflicting } \\
\text { studies: }\end{array}$ & Buss $2006 ;$ Erling 2007; Spannring 2008; Thorpe 2008; 2017 \\
\hline
\end{tabular}


Table 11 CERQual evidence profile. F9: National or cultural identity loss is the biggest perceived threat of endorsing a European identity. Category: Predictors of endorsement and opposition

\begin{tabular}{ll}
\hline \multicolumn{2}{c}{ Assessment for each CERQual component } \\
$\begin{array}{ll}\text { Methodological } \\
\text { limitations }\end{array}$ & N/VMC \\
Coherence & $\begin{array}{l}\text { Minor concerns regarding coherence due to contradictory } \\
\text { findings in one study }\end{array}$ \\
Relevance & N/VMC \\
Adequacy & Moderate concerns regarding adequacy due to limited \\
& number of contributing studies \\
\hline $\begin{array}{l}\text { Overall } \\
\text { CERQual } \\
\text { assessment: }\end{array}$ & Moderate confidence \\
\hline $\begin{array}{l}\text { Contributing } \\
\text { studies: }\end{array}$ & Du Bois-Reymond 1998; Licata 2003; Grundy 2007 \\
\hline $\begin{array}{l}\text { Conflicting } \\
\text { studies: }\end{array}$ & Spannring 2008 \\
\hline
\end{tabular}

N/VMC no or very minor concerns

and European integration, even in a time of economic crisis [12]. However, the results of individual studies greatly fluctuate on their appraisal of academic sojourns abroad. The development of a European identity through student mobility is not self-evident for all European countries and is subject to regional variation [3]. Additionally, some results seem to indicate that European mobile students are a priori already significantly oriented towards Europe, before they partake in the experience abroad [3]. One study concluded that the positive effect of

Table 12 CERQual evidence profile. F10: Academic sojourns have a positive impact on students' support for the EU. Category:

Predictors of endorsement and opposition

\begin{tabular}{ll}
\hline \multicolumn{2}{c}{ Assessment for each CERQual component } \\
$\begin{array}{ll}\text { Methodological } \\
\text { limitations }\end{array}$ & N/VMC \\
\hline Coherence & $\begin{array}{l}\text { Moderate concerns due to contradictory findings in three } \\
\text { of the studies }\end{array}$ \\
\hline $\begin{array}{l}\text { Relevance } \\
\text { Ndequacy }\end{array}$ & N/VMC \\
\hline $\begin{array}{l}\text { Overall } \\
\text { CERQual } \\
\text { assessment: }\end{array}$ & Moderate confidence \\
\hline $\begin{array}{l}\text { Contributing } \\
\text { studies: }\end{array}$ & Udrea 2013; Van Mol 2013; Hadfield 2016 \\
\hline $\begin{array}{l}\text { Conflicting } \\
\text { studies: }\end{array}$ & Osler 1998; Genova 2016; Llurda 2016 \\
\hline
\end{tabular}


sojourns was limited to fostering positive feelings towards the culture of the host territory and towards the home country, but not towards Europe as a whole [18]. In Llurda's work (2016), the extent of the impact correlates to the level of Europeanness of the host country. Thus, students sojourning in the 'least European country' (the UK) feel they would probably experience a deeper feeling of Europeanness elsewhere, like in countries such as Belgium or Germany.

Two studies reported the detrimental effects of foreign country academic experiences caused by indifferent and occasionally hostile attitudes of students in the host country. In this sense, informants either expressed the difficulty to gain access to the people and cultures of their host countries [24] or negative rhetoric encountered abroad. 'The overarching negativity in the host society ultimately results in strengthening participants' sense of national belonging' (Genova [10], 8). Llurda also referred a heightened sense of national identity post experience abroad. The results suggest that the detrimental effects could be minimised by inducting exchange students into the social and academic life of the host community [24].

Finding 11 reveals that exposure through leisure or spontaneous travel to Europe facilitates students' European identification (Table 13)

The relevance of boundary-crossing experiences and international travelling is highlighted as a means to achieving open-mindedness, curiosity and identity changes or identities in flux (hybridity and nonexclusivity in national and regional identities), which may facilitate the adoption of a European identity [33]. Two studies report an explicit causality between personal experiences of stays abroad, as well as a more prominent inclusion of a European aspect in one's selfidentity ([9] [32]). The increased levels of identification with Europe are explained by the exposure to other cultures which occurs by travelling abroad or having immediate family members residing in other countries. Sojourners' self-perceptions and identifications were often influenced by the way they were perceived or labelled by local, international and co-national people they interact with while in other countries. A further way to explore exposure is through personal migration experiences that the young person has had if they have lived elsewhere or when close members of their immediate family have had such an experience [32]. Nevertheless, one study conducted in a British setting concluded that travel to continental Europe along with exposure to European culture do not necessarily result in a sense of belonging to Europe [34].

Finding 12 indicates that intentional pedagogic interventions are suited to raise European awareness (Table 14).

The seven contributing studies address the importance of cognitive mobilisation [12, 32], citizenship education [40], cultural capital oriented to Europe [34], intercultural understanding and comparative education $[8,24]$ to support the development of a relational identification with Europe. Hence, the findings underpin empirically the need for actively incorporating 'Conscious Europeanism' citizenship contents into the existing curricula. Similarly, another study [11] corroborated that although

Table 13 CERQual evidence profile. F11: Exposure through leisure or spontaneous travel to Europe facilitates students' European identification. Category: Foreign countries experiences

\begin{tabular}{ll}
\hline \multicolumn{2}{c}{ Assessment for each CERQual component } \\
$\begin{array}{ll}\text { Methodological } \\
\text { limitations }\end{array}$ & N/VMC $=$ No or very minor concerns \\
\hline $\begin{array}{l}\text { Coherence } \\
\text { Relevance }\end{array}$ & $\begin{array}{l}\text { Minor concerns due to contradictory findings in one of } \\
\text { the studies }\end{array}$ \\
$\begin{array}{l}\text { Adequacy } \\
\text { N/VMC }\end{array}$ & $\begin{array}{l}\text { Moderate concerns due to limited number of contributing } \\
\text { studies }\end{array}$ \\
\hline $\begin{array}{l}\text { Overall } \\
\text { CERQual } \\
\text { assessment: }\end{array}$ & Moderate confidence \\
\hline $\begin{array}{l}\text { Contributing } \\
\text { studies: }\end{array}$ & Fuss $2006 ;$ Grundy 2007; Spannring 2008 \\
\hline $\begin{array}{l}\text { Conflicting } \\
\text { studies: }\end{array}$ & Thorpe 2008 \\
\hline
\end{tabular}


Table 14 CERQual evidence profile. F12: Intentional pedagogic interventions are desirable to raise European awareness. Category: Foreign countries experiences

\begin{tabular}{ll}
\hline \multicolumn{2}{c}{ Assessment for each CERQual component } \\
\\
$\begin{array}{ll}\text { Methodological } \\
\text { limitations }\end{array}$ & $\begin{array}{l}\text { Minor concerns due to poor reporting from 1 study } \\
\text { (Fernández) on collected evidence (does not include } \\
\text { direct quotes from respondents) }\end{array}$ \\
$\begin{array}{ll}\text { Coherence } \\
\text { N/VMC }\end{array}$ \\
$\begin{array}{ll}\text { Relevance } \\
\text { Adequacy }\end{array}$ & N/VMC \\
\hline $\begin{array}{l}\text { Overall } \\
\text { CERQual } \\
\text { assessment: }\end{array}$ & High confidence \\
\hline $\begin{array}{l}\text { Contributing } \\
\text { studies: }\end{array}$ & Osler 1998; Fernández 2005; Spannring 2008; Thorpe \\
\hline
\end{tabular}

N/VMC no or very minor concerns

deliberate interventions to foster civic engagement among Europeans, such as town-twinning or schoolexchange experiences, were infrequent, they raised the awareness of pupils.

\section{Discussion and conclusions}

In the CERQual assessment of each finding, authors have determined that the research methods used in the primary studies may in some cases limit the applicability and completeness of the data reported. All the included studies made use of individual or group interviews and focus group discussions as their main method of data collection, and none used long-term ethnographic methods.

Taken together, the findings presented suggest a rather generic representation of community ethos, characterised by plurilingual and multicultural societies which ideally abide by 'European values' and uphold democracy and human rights. It can also be concluded that university students' identification as Europeans is subsidiary to, but also compatible with, their more salient and emotion laden national and regional identities. As it has been shown, European identity is contextually bound and surfaces more frequently during transnational experiences and encounters with international peers. However, the youngsters' endorsement of the EU is consistently associated to economic preoccupations and assumptions that membership can have practical benefits for the citizens' everyday life and future prospects. In this sense, the Commission's communication campaigns and educational initiatives tackling the utilitarian aspects of
European citizenship seem to have permeated the students' collective worldview.

Nevertheless, civic duties, policies and supranational decision-making seem too far-removed to be of any consequence in young Europeans' daily activity. An implication of this is the need to instigate structural changes on a national and local level to ensure that youngsters receive better knowledge about the EU and their means of active participation in the EU decision-making process.

Endorsing curricula which address European public space in a transversal way, both at the higher education stage and at the preceding levels of the education system, would possibly contribute to a citizenfriendly EU and a greater popular ownership of European matters. Reinforcing the European Dimension in Education which transcends individualistic views and relies on value-based approaches would stimulate greater identification with Europe. Thus, an inclusive Europe-oriented education, covering responsible citizenship, multiple identities and citizens' dialogue should be central to the EU's lifelong learning agenda, reaching all stages of informal, nonformal and formal education, particularly that of the higher education realm. We concur with Diestro Fernández [4] in that future educational policies should envisage a broadly defined European studies curriculum which considers differentiated narratives and focuses on social endeavours, dialogue, solidarity and plurality in order to mobilise these young adults in support of the European process and to strengthen their European identity. 
As much as a valuable tool for intercultural understanding, the command of foreign languages is recurrently identified as a predictor of endorsement of the EU. In fact, mobile students display more pro-European attitudes than their non-mobile fellows, but whether this results from the experience abroad or predates it is an unsettled issue. Foreign language learning is generally acknowledged for its contributing effect to inter-personal communication and socialisation during transnational experiences, leading to the development of cosmopolitan dispositions. In this sense, the EU's continuing commitment with plurilingual education seems to be particularly fitting for the promotion of European citizenship.

Both academic sojourns and leisure transnational experiences chiefly have a positive impact on the students' perceptions about the EU and broaden their own civic and cultural identities; however, either of them would benefit from intentional pedagogical interventions to fully address the current discussion on the future of Europe. By supplementing the students' European cultural capital and equipping them for the challenges of globalism, complexity and the unequal distribution of opportunities throughout European societies, education has the means to better prepare young citizens for intercultural dialogue and democratic participation.

Some implications for further research need also to be mentioned. From a heuristic perspective, the need for researcher reflexivity in future qualitative studies on the phenomena of interest examined in this review has been established. Regarding the thematic categories analysed, it is deemed that more detail concerning setting and participants is also needed to identify underlying cultural or social phenomena (shared values or beliefs) that mediate the influence of study programmes abroad.

High confidence has been placed in the evidence contributing to several review findings, especially those concerning the relationships between national and European identities. However, further research, especially dealing with cross-border individual practices, both academic and spontaneous, whose positive impact on European identification is not consistently corroborated, could strengthen evidence for the findings where moderate confidence was awarded. In turn, such additional empirical evidence would fully substantiate the European Union's education policy agenda and justify mobility programme funding in the years to come.

\section{Acknowledgements}

Not applicable

\section{Authors' contributions}

Conceptualization and investigation, ECB, MCMG, MCFM; methodology and formal analysis, ECB, MCMG; Writing - Original Draft, ECB, MCMG, MCFM; Writing - Review \& Editing, ECB, MCMG, MCFM; funding acquisition, MCFM, MCMG. All authors read and approved the final manuscript.

\section{Authors' information}

Esther Cores-Bilbao is a doctoral candidate at the University of Huelva with interests in identity and European cultural literacy, interculturality, language learning and motivation in adult education. She is the Head Teacher at the EOI Do Mundo Lume, a government funded Official School of Languages for adults. She is an external advisor to the Spanish National Agency for the Internationalisation of Education (SEPIE), having evaluated Erasmus+ proposals since 2014. She has coordinated several international projects in the Adult Education sector and cooperates with the Language Policy Division/ Unit of the Council of Europe by participating in the project "CEFR mediation strategies: towards a socio-emotional and plurilingual education". She is also the lead researcher of the Education Research Project "Identity and Cultural Literacy: the use of Music Videos in English Language Teaching to Adults" (PIV-002//17) supported by the Andalusian Department of Education. María del Carmen Méndez-García is a senior lecturer at the Department of English Philology, University of Jaén. She has researched on the cultural component in EFL material, intercultural competence and intercultural communication. She has participated in international projects such as 'International Competence for Professional Mobility', funded by the European Commission. She has cooperated with the Language Policy Division/Unit of the Council of Europe in the development of the Autobiography of Intercultural Encounters and the Autobiography of Intercultural Encounters through Visual Media.

M. Carmen Fonseca-Mora is full professor at the Department of English Studies, University of Huelva, Spain. She has widely published on foreign language education policy and cooperates with the Language Policy Division/ Unit of the Council of Europe participating in the project "CEFR mediation strategies: towards a socio-emotional and plurilingual education". She is also the principal research investigator of the R+D project on "intercultural literacy of European university students" (FFI2016-75452-R) funded by the Spanish Research Ministry.

\section{Funding}

This study has been supported by the R+D project 'Musical aptitude, reading fluency and intercultural literacy of European university students' (FFI201675452-R), funded by the Spanish Ministerio de Economía, Industria y Competitividad, and by the Research Group HUM 679 of the Junta de Andalucía, Estudios de Lingüística Aplicada a la Enseñanza del Inglés.

\section{Availability of data and materials}

The datasets used and/or analysed during the current study are available from the corresponding author on reasonable request.

Ethics approval and consent to participate

Not applicable

Consent for publication

Not applicable

\section{Competing interests}

The authors declare that they have no competing interests.

\section{Author details}

1Departamento de Pedagogía, Facultad de Educación, Psicología y Ciencias del Deporte, Universidad de Huelva, Avda. de las Fuerzas Armadas, s/n, 21071 Huelva, Spain. ${ }^{2}$ Departamento de Filología Inglesa, Facultad de Humanidades y Ciencias de la Educación, Universidad de Jaén, Paraje las Lagunillas s/n, 23071 Jaén, Spain. ${ }^{3}$ Departamento de Filología Inglesa, Facultad de Humanidades, Universidad de Huelva, Avda.Tres de Marzo s/n, 21071 Huelva, Spain.

Received: 16 August 2019 Accepted: 22 October 2019

Published online: 06 January 2020

\section{References}

1. Byram M, Hu A, Rahman M (2017) Are researchers in Europe European researchers? A study of doctoral researchers at the University of Luxembourg*. Studies in Higher Education 0(0):1-13 https://doi.org/10. 1080/03075079.2017.1378634 
2. Capello R (2018) Cohesion Policies and the Creation of a European Identity: The Role of Territorial Identity. J Common Mark Stud 56(3):489-503 https:// doi.org/10.1111/jcms.12611

3. Critical Appraisal Skills Programme (2018). CASP (Qualitative) Checklist [online] Available at: https://casp-uk.net/casp-tools-checklists/. Accessed: 28th.January 2019.

4. Diestro Fernández A (2014) The future of European education: a political strategy \& four action areas. Eur J Futures Res 2(1) https://doi.org/10.1007/s40309-014-0049-2

5. Du Bois-Reymond M (1998) European identity in the young and Dutch students' images of Germany and the Germans. Comparative Educ 34(1):2740 https://doi.org/10.1080/03050069828324

6. Duchesne S (2010) L'identité européenne, entre science politique et science fiction. Politique Européenne 30(1):7 https://doi.org/10.3917/poeu.030.0007

7. Erling, E.J., (2007) Local identities, global connections: affinities to English among students at the Freie Universität Berlin. World Englishes 26 (2):111-130

8. Fernández Ó (2005) Towards European citizenship through hegher Education? Eur J Educ 40(1):59-68 https://doi.org/10.1016/j.jaci.2009.11.036

9. Fuss D, Grosser M (2006) What makes young Europeans feel European? Results from a cross-cultural research proyect. European Identity, Theoretical Perspectives and Empirical Insights, pp 209-242

10. Genova E (2016) To have both roots and wings: nested identities in the case of Bulgarian students in the UK. Identities 23(4):392-406. https://doi. org/10.1080/1070289X.2015.1024125

11. Grundy S, Jamieson L (2007) European identities: from absent-minded citizens to passionate Europeans. Sociol 41(4):663-680 https://doi.org/10 $1177 / 0038038507078919$

12. Hadfield A, Summerby-Murray R (2016) Vocation or vocational? Reviewing European Union education and mobility structures. Eur J Higher Educ 6(3): 237-255 https://doi.org/10.1080/21568235.2015.1099453

13. Healy M, Richardson M (2017) Images and identity: children constructing a sense of belonging to Europe. Eur Educ Res J 16(4):440-454 https://doi.org/ $10.1177 / 1474904116674015$

14. Keating A (2016) Are cosmopolitan dispositions learned at home, at school, or through contact with others? Evidence from young people in Europe. J Youth Stud 19(3):338-357 https://doi.org/10.1080/13676261.2015.1072617

15. Lewin S, Bohren M, Rashidian A, Munthe-Kaas H, Glenton C, Colvin CJ et al (2018a) Applying GRADE-CERQual to qualitative evidence synthesis findingspaper 2: how to make an overall CERQual assessment of confidence and create a Summary of Qualitative Findings table. Implementation Science 13(Suppl 1) https://doi.org/10.1186/s13012-017-0689-2

16. Lewin S, Booth A, Glenton C, Munthe-Kaas H, Rashidian A, Wainwright M et al (2018b) Applying GRADE-CERQual to qualitative evidence synthesis findings: introduction to the series. Implementation Science 13(Suppl 1):110 https://doi.org/10.1186/s13012-017-0688-3

17. Licata, L. (2003). Representing the future of the European Union : Consequences on national and European identifications. Online, 12, 1-22.

18. Llurda E, Gallego-Balsà L, Barahona C, Martin-Rubió X (2016) Erasmus student mobility and the construction of European citizenship. Language Learning Journal 44(3):323-346 https://doi.org/10.1080/09571736.2016.1210911

19. Mitchell K (2012) Student mobility and European identity: Erasmus study as a transformative experience. J Contemp Eur Res 8(4):490-518 Retrieved from http://www.imagining.eu/workshop/papers/MITCHELL-Student mobility and European identity.pdf

20. Mitchell K (2015) Rethinking the "Erasmus Effect" on European Identity. Common Mark Stud 53(2):330-348 https://doi.org/10.1111/jcms.12152

21. Munthe-Kaas H, Bohren MA, Glenton C, Lewin S, Noyes J, Tunçalp Ö et al (2018) Applying GRADE-CERQual to qualitative evidence synthesis findingspaper 3: how to assess methodological limitations. Implementation Sci 13(Suppl 1) https://doi.org/10.1186/s13012-017-0690-9

22. Noyes, J. P., Popay, J., Pearson, A., \& Hannes, K. (2008). Chapter 20 Qualitative research and Cochrane reviews, (October 2017). https://doi.org/ 10.1002/9780470712184.ch20

23. Oborune K (2013) Becoming more European after ERASMUS ? The impact of the ERASMUS programme on political and cultural identity. Epiphany: Journal of Transdisciplinary Studies 6(1):182-202

24. Osler A (1998) European citizenship and study abroad: student teachers' experiences and identities. Camb J Educ 28(1):77-96 https://doi.org/10. 1080/0305764980280107

25. Petticrew, M., \& Roberts, H. (2006). Systematic Reviews in the Social Sciences: a practical guide. Blackwell Publishing. https://doi.org/10.1002/9780470754887
26. Pollmann A (2007) National and European identities: notions of reconcilability and inclusiveness in a case study of German trainee teachers. Compare 37(1):89-104 https://doi.org/10.1080/ 03057920601061844

27. Polonska-Kimunguyi $E$, Kimunguyi $P$ (2011) The making of the Europeans: media in the construction of pan-national identity. International Communication Gazette 73(6):507-523 https://doi.org/10.1177/1748048511412283

28. Recchi E (2014) Pathways to European identity formation: a tale of two models. Innovation 27(2):119-133 https://doi.org/10.1080/13511610.2013.873709

29. Ros M, Miryam R, Casado C (2008) Valores e identidades nacional y Europea: Un estudio transcultural. Revista de Psicologia Social 23(3):367-376 https:// doi.org/10.1174/021347408785843051.

30. Shore C (2006) "In uno plures" (?) EU cultural policy and the governance of Europe. Critical Analysis 5:7-26

31. Sigalas E (2010) Cross-border mobility and european identity: the effectiveness of intergroup contact during the ERASMUS year abroad. Eur Union Polit 11(2):241-265 https://doi.org/10.1177/1465116510363656

32. Spannring $R$, Wallace C, Datler G (2008) What leads young people to identify with Europe? An exploration of the impact of exposure to europe and political engagement on European identity among young Europeans. Perspect Eur Polit Soc 9(4):480-498 https://doi.org/10.1080/ 15705850802416929

33. Sperling J (2013) Belonging, beyond the nation: the significance and meaning of European identity for Latin American-origin youth in Spain. National Identities 15(1):67-84 https://doi.org/10.1080/14608944.2012.733155

34. Thorpe C (2008) The distinguishing function of European identity: attitudes towards and visions of Europe and the European Union among young scottish adults. Perspect Eur Polit Soc 9(4):499-513 https://doi.org/10.1080/ 15705850802416945

35. Udrea (2013) National and European identity: an empirical research on how Romanian students experience identities during their long-term studies abroad. Rom J Commu Public Relat 15(1(28)):17-35

36. Brande, L. Van Den. (2017). Reaching out to EU citizens: a new opportunity. https://doi.org/10.2775/319

37. Van Mol C (2018) Becoming Europeans: the relationship between student exchanges in higher education, European citizenship and a sense of European identity. Innovation 1610:1-15 https://doi.org/10.1080/13511610. 2018.1495064

38. Van Mol, C. (2013) Intra-European Student Mobility and European Identity: A Successful Marriage?. Population, Space and Place 19 (2):209-222.

39. Wilson I (2011) What should we expect of "Erasmus generations"? J Comm Mark Stud 49(5):1113-1140 https://doi.org/10.1111/j.1468-5965.2010.02158.x

40. Wilkins, C., Busher, H., Lawson, T., Acun, I., Leman Göz, N. (2010) European Citizenship and European Union Expansion: Perspectives on Europeanness and. Citizenship Education from Britain and Turkey. European Educational Research Journal 9 (4):444-456.

\section{Publisher's Note}

Springer Nature remains neutral with regard to jurisdictional claims in published maps and institutional affiliations.

\section{Submit your manuscript to a SpringerOpen ${ }^{\circ}$ journal and benefit from:}

- Convenient online submission

- Rigorous peer review

- Open access: articles freely available online

- High visibility within the field

- Retaining the copyright to your article

Submit your next manuscript at $>$ springeropen.com 